\title{
Study on effect of different salinity on growth and morphological traits of nerium cultivars (Nerium oleander \\ L.)
}

\section{N Sugadev, PA Arasu, A Beaulah, P Saravanapandian \& R Amutha}

Journal of Agriculture and Ecology

\section{Journal of Agriculture and Ecology}

ISSN: 2456-9410

Volume: 6

Journal of Agriculture and Ecology (2018) 6: 22-30 http://doi.org/10.53911/JAE.2018.6203 


\title{
Study on effect of different salinity on growth and morphological traits of nerium cultivars (Nerium oleander $\mathbf{L}$.)
}

\author{
N Sugadev ${ }^{1} \nabla$, PA Arasu ${ }^{2}$, A Beaulah $^{3}$, P Saravanapandian $^{4} \& \mathrm{R} \mathrm{Amutha}^{5}$ \\ ${ }^{I}$ Department of Floriculture and Landscaping, HC \& RI, TNAU, Coimbatore - 03 \\ ${ }^{2}$ Horticultural Research Station, Yercaud - 636601 \\ ${ }^{3}$ Department of Horticulture, AC \& RI, TNAU, Madurai - 625104 \\ ${ }^{4}$ Department of Soils and Environment, AC \& RI, TNAU, Madurai - 625104 \\ ${ }^{5}$ Department of Seed Science and Technology, AC \& RI, TNAU, Madurai - 625104 \\ Corresponding author: N Sugadev, E-mail: sugadevnatarajan@gmail.com
}

\section{Article Info}

Article history

Received: 30 July 2018

Accepted: 03 August 2018

Available online: 25

September 2018

Key Words: Nerium, salt stress, growth, morphology.

\begin{abstract}
Six cultivars of Nerium (Single Pink, Single White, Single Red, Double Pink, Double White and Double Red) were evaluated to identify the salt tolerant cultivars on basis of growth and morphological parameters. This study was carried out in Department of Horticulture, Agricultural College and Research Institute, Tamil Nadu Agricultural University, Madurai. These cultivars were transplanted polybags with soils of four different salt levels includes control $\left(\mathrm{S}_{1}-0.87 \mathrm{dS} \mathrm{m} \mathrm{m}^{-1}\right)$, low saline $\left(\mathrm{S}_{2}-3.94 \mathrm{dS} \mathrm{m} \mathrm{m}^{-1}\right)$, medium saline $\left(\mathrm{S}_{3}-5.78 \mathrm{dS} \mathrm{m}^{-1}\right)$ and high saline $\left(\mathrm{S}_{4}-7.85 \mathrm{dS} \mathrm{m}^{-1}\right)$ along with $2 \mathrm{dS}$ $\mathrm{m}^{-1}$ saline water (by dissolving $\mathrm{NaCl}, \mathrm{CaCl}_{2}$ and $\mathrm{MgCl}_{2}$ ) was irrigated based on moisture availability. The parameter viz., plant height $(84.53 \mathrm{~cm})$, number of leaves per plant (1.09), leaf area $\left(1773.32 \mathrm{~cm}^{2}\right)$, stem thickness $(3.12 \mathrm{~cm})$, number of branches $(1.09)$, root length $(28.87 \mathrm{~cm})$, root dry weight $(25.59 \mathrm{~g})$, internodal length $(4.01 \mathrm{~cm})$ and survival percentage $(94.33 \%)$ was recorded. All parameters show significant decrease with increasing salinity. In cultivar Single Red plant height was high and low height was observed in Double Pink at high salinity. Double Red cultivar shows more tolerance to all salinity levels, but Double pink have more salinity symptoms and shows less tolerance.
\end{abstract}

Copyright (C2018 Sugadev et al., This is an open access article published under the terms of the Creative Commons Attribution License, which permits unrestricted use, distribution, and reproduction in any medium, provided the original work is properly cited.

Preferred citation: Sugadev N, Arasu PA, Beaulah A, Saravanapandian P \& Amutha R. 2018. Study on effect of different salinity on growth and morphological traits of nerium cultivars (Nerium oleander L.). Journal of Agriculture and Ecology, 6: 2230; http://doi.org/10.53911/JAE.2018.6203.

\section{Introduction}

Nerium (Nerium oleander L.) is an evergreen shrub of family Apocynaceae (dogbane). Nerium oleander is mostly grown as an ornamental plant in arid and semi-arid regions, as it requires little water and nutrients 
with very minimum maintenance. Nerium is a versatile crop with vital roles in soil reclamation, urban tolerant, screen plant, and highway median. Oleander survives drought and can grow well in poor soils, even tolerating salt spray, brackish water and alkaline soil. In total $19.5 \%$ of agricultural productive lands are saline (Flowers \& Yeo 1995) and increasing salinity in each year about $1 \%$ of total land, which reduces the crop productivity (Allah 1996). Salt stress in soils or water is one of the major abiotic stress especially in arid and semi-arid regions and can severely limit plant growth and productivity (Allakhverdier et al. 2000). The main detrimental effect of salinity on oleander plants was result of decreasing growth rate and leaf damage (Munns \& Termatt 1986). After transplant establishment phases was critical to plants for successful landscaping projects (Whitcomb 1986). The aim of this study was to investigate effect of salinity stress on growth and morphological traits of nerium cultivars. Growth is reduced by salinity by several distinct processes, which are related either to the accumulation of salt, or which are independent of shoot salt accumulation. These can be experimentally distinguished by measuring effects immediately (within minutes to a few days) upon addition of salt (before there has been time for salt to accumulate in the shoot) or measured after much longer times (several days to weeks), after there has been time for salt to accumulate in the shoot and affect shoot growth (Roy et al. 2014).

\section{Materials and Methods}

An experiment was conducted to screen the nerium cultivars for different levels of salinity in soil at Agricultural College and Research Institute, Tamil Nadu Agricultural University, Madurai at $9^{0} 58^{\prime} 12^{\prime \prime}$ North latitude and $78^{0} 12^{\prime} 27^{\prime \prime}$ East latitude during 2017-2018. Five month old saplings with uniform height were selected for experiment. The selected saplings were transplanted in grow bags dimension of 20 " x 18 ". The study was designed under Factorial Completely Randomised Design (FCRD) with two factors and three replications. The soils of different salinity levels viz., 0.87, 3.94, 5.78 and 7.85 $\mathrm{dS} \mathrm{m} \mathrm{m}^{-1}$ were collected from different salt affected places and used for treatments along with control. Irrigated water was used throughout the experiment period at a level of $2 \mathrm{dS} \mathrm{m}^{-1}$ by dissolving $\mathrm{NaCl}, \mathrm{CaCl}_{2}$ and $\mathrm{MgCl}_{2}$ except in control. Four month old saplings were transplanted to polybags containing saline soil with defined electrical conductivity. Irrigation was applied manually based on soil moisture availability. Tap water was applied upto 15 days for sapling establishment. Saline water was applied after establishment to end of treatment. The cultivars used in this study are Single Pink, Single White, Single Red, Double Pink, Double White and Double Red. The observations on growth and morphological parameters were recorded with respect to various salinity levels.

Observations on plant height $(\mathrm{cm})$, total number of leaves per plant, leaf area $\left(\mathrm{cm}^{2}\right)$, stem thickness $(\mathrm{cm})$, number of primary branches, root length $(\mathrm{cm})$, root dry weight $(\mathrm{g})$, internodal length $(\mathrm{cm})$ and survival 
percentage were recorded. The parameters such as plant height, total number of leaves per plant, leaf area and stem thickness were observed at bimonthly interval, whereas the remaining parameters were noted during final stage of experiment. All the parameters were measured based on standard procedure. The data were analysed by using AGRES Software version 3.01. Mean, standard error difference, coefficient of variation and critical difference were obtained from above analysis. The experimental conclusions were drawn only on significant differences between the treatment means at $0.05 \%$ level of significance.

\section{Results and Discussion}

The stress condition on morphological parameters reduced the number of shoots, stem diameter and root dry weight of nerium plant (Banon et al. 2006). Plant growth and dry matter accumulation was severely affected by salinity stress in Prunus armeniaca described by Rodriguez et al. (2005). Salinity stress tolerance capacity of plant can also determine the height of plant represented in
Table 1. In our study highest plant height was observed in Single Red at control. At 7.85 dS $\mathrm{m}^{-1}$ the maximum height was recorded in Single Red $(66.77 \mathrm{~cm})$ and the minimum height was recoded in Double Pink (50.20 $\mathrm{cm})$. The decreased in number of primary branches per plant was observed in all the cultivars. The highest number of branches was observed in Double Red with control (2.50) and lowest number of branches was observed in Double Pink with high salinity (0.00). The higher concentration of salty ions in aerial parts of plant might be mainly due to higher accumulation (hyperionic) of sodium content. All the cultivars of nerium show reduction in leaf numbers. Maximum number of leaves (77.05) was observed in control $\left(0.87 \mathrm{dS} \mathrm{m}^{-1}\right)$, low (21.28) was observed in Double Pink at high level $\left(7.85 \mathrm{dS} \mathrm{m}^{-1}\right)$. The early senescence and abscission of leaf was achieved due the presence of high sodium and chloride content in mature and older leaves. This will lead to decreased in number of leaves which ultimately reduces the total leaf area of plants.

Table 1. Effect of different salinity levels on plant height, number of primary branches and number of leaves

\begin{tabular}{ccccc}
\hline Cultivar & $\begin{array}{c}\text { Salinity } \\
\text { levels }\end{array}$ & Plant height $(\mathrm{cm})$ & $\begin{array}{c}\text { Number of primary } \\
\text { branches }\end{array}$ & $\begin{array}{c}\text { Number of leaves/ } \\
\text { plant }\end{array}$ \\
\hline \multirow{4}{*}{ Single Pink } & $\mathrm{S}_{1}$ & 124.37 & 0.63 & 62.00 \\
& $\mathrm{~S}_{2}$ & 66.08 & 0.50 & 38.78 \\
& $\mathrm{~S}_{3}$ & 65.27 & 0.37 & 32.94 \\
& $\mathrm{~S}_{4}$ & 61.29 & 0.88 & 27.45 \\
& $\mathrm{~S}_{1}$ & 103.54 & 1.88 & 76.39 \\
Single White & $\mathrm{S}_{2}$ & 72.07 & 0.38 & 43.89 \\
& $\mathrm{~S}_{3}$ & 62.90 & 0.25 & 36.13 \\
& $\mathrm{~S}_{4}$ & 59.02 & 0.12 & 33.86 \\
& $\mathrm{~S}_{1}$ & 123.35 & 1.13 & 61.50 \\
& $\mathrm{~S}_{2}$ & 74.70 & 0.62 & 41.67 \\
& $\mathrm{~S}_{3}$ & 73.29 & 0.50 & 38.67 \\
& $\mathrm{~S}_{4}$ & 66.77 & 0.13 & 33.11
\end{tabular}




\begin{tabular}{|c|c|c|c|c|c|c|c|c|c|c|}
\hline \multirow{4}{*}{ Double Pink } & $\mathrm{S}_{1}$ & \multicolumn{3}{|c|}{102.98} & \multicolumn{3}{|c|}{0.75} & \multicolumn{3}{|c|}{56.67} \\
\hline & $S_{2}$ & \multicolumn{3}{|c|}{51.92} & \multicolumn{3}{|c|}{0.13} & \multicolumn{3}{|c|}{30.94} \\
\hline & $\mathrm{S}_{3}$ & \multicolumn{3}{|c|}{50.57} & \multicolumn{3}{|c|}{0.12} & \multicolumn{3}{|c|}{26.28} \\
\hline & $\mathrm{S}_{4}$ & \multicolumn{3}{|c|}{50.20} & \multicolumn{3}{|c|}{0.00} & \multicolumn{3}{|c|}{21.28} \\
\hline \multirow{4}{*}{ Double White } & $S_{1}$ & \multicolumn{3}{|c|}{102.08} & \multicolumn{3}{|c|}{1.37} & \multicolumn{3}{|c|}{68.94} \\
\hline & $\mathrm{S}_{2}$ & \multicolumn{3}{|c|}{67.13} & \multicolumn{3}{|c|}{0.50} & \multicolumn{3}{|c|}{41.56} \\
\hline & $\mathrm{S}_{3}$ & \multicolumn{3}{|c|}{64.52} & \multicolumn{3}{|c|}{0.13} & \multicolumn{3}{|c|}{30.05} \\
\hline & $\mathrm{S}_{4}$ & \multicolumn{3}{|c|}{63.16} & \multicolumn{3}{|c|}{0.12} & \multicolumn{3}{|c|}{28.50} \\
\hline \multirow{4}{*}{ Double Red } & $S_{1}$ & \multicolumn{3}{|c|}{115.17} & \multicolumn{3}{|c|}{2.50} & \multicolumn{3}{|c|}{77.05} \\
\hline & $\mathrm{S}_{2}$ & \multicolumn{3}{|c|}{59.95} & \multicolumn{3}{|c|}{0.75} & \multicolumn{3}{|c|}{55.61} \\
\hline & $\mathrm{S}_{3}$ & \multirow{2}{*}{\multicolumn{3}{|c|}{$\begin{array}{l}56.45 \\
55.08\end{array}$}} & \multirow{2}{*}{\multicolumn{3}{|c|}{$\begin{array}{l}0.62 \\
0.50 \\
\end{array}$}} & \multirow{2}{*}{\multicolumn{3}{|c|}{$\begin{array}{l}53.61 \\
41.39\end{array}$}} \\
\hline & $\mathrm{S}_{4}$ & & & & & & & & & \\
\hline Interactions & & V & S & $\mathrm{V} \times \mathrm{S}$ & V & S & $\mathrm{V} \times \mathrm{S}$ & V & S & $\mathrm{V} \times \mathrm{S}$ \\
\hline $\mathrm{CD}(\mathrm{P}=0.05)$ & & 3.28 & 2.68 & 6.56 & 0.0252 & 0.0206 & 0.0504 & 6.49 & 5.30 & NS \\
\hline
\end{tabular}

This result was analogous to Alvarez to the presence of sodium and chloride ions et al. (2012) in Phlomis purpurea plant, while that create nutritional imbalance and increased in salinity stress in soil reduced the decreased the metabolic activity of plants (Rai ionic balance in plant parts and collapse et al. 2003). The membrane instability and metabolic activity and membrane permeability other nutrient imbalance (potassium, calcium, by ion toxicity. The reduction of plant height etc.) in plant will reduce the cell division and in a saline habitat reduces the osmotic other anabolic processes.

potential in root zone areas which may be due

Table 2. Effect of different salinity levels on leaf area, stem diameter and survival percentage

\begin{tabular}{ccccc}
\hline Cultivar & $\begin{array}{c}\text { Salinity } \\
\text { levels }\end{array}$ & Leaf area $\left(\mathrm{cm}^{2}\right)$ & Stem diameter $(\mathrm{cm})$ & $\begin{array}{c}\text { Survival } \\
\text { percentage }(\%)\end{array}$ \\
\hline \multirow{5}{*}{ Single Pink } & $\mathrm{S}_{1}$ & 3555.43 & 3.50 & 100.00 \\
& $\mathrm{~S}_{2}$ & 559.63 & 2.91 & 86.00 \\
& $\mathrm{~S}_{3}$ & 355.34 & 2.65 & 80.00 \\
& $\mathrm{~S}_{4}$ & 311.77 & 2.52 & 73.33 \\
& $\mathrm{~S}_{1}$ & 3266.77 & 3.67 & 100.00 \\
Single White & $\mathrm{S}_{2}$ & 892.92 & 2.83 & 95.55 \\
& $\mathrm{~S}_{3}$ & 504.96 & 2.71 & 88.89 \\
& $\mathrm{~S}_{4}$ & 406.59 & 2.35 & 75.55 \\
\multirow{5}{*}{ Single Red } & $\mathrm{S}_{1}$ & 3402.18 & 3.41 & 100.00 \\
& $\mathrm{~S}_{2}$ & 614.67 & 2.83 & 93.11 \\
& $\mathrm{~S}_{3}$ & 520.73 & 2.31 & 86.00 \\
& $\mathrm{~S}_{4}$ & 411.31 & 2.65 & 82.00 \\
Double Pink & $\mathrm{S}_{1}$ & 2550.00 & 3.37 & 84.00 \\
& $\mathrm{~S}_{2}$ & 694.17 & 2.33 & 73.33 \\
& $\mathrm{~S}_{3}$ & 352.96 & 2.28 & 57.78 \\
Double White & $\mathrm{S}_{4}$ & 264.48 & 1.83 & 100.00
\end{tabular}




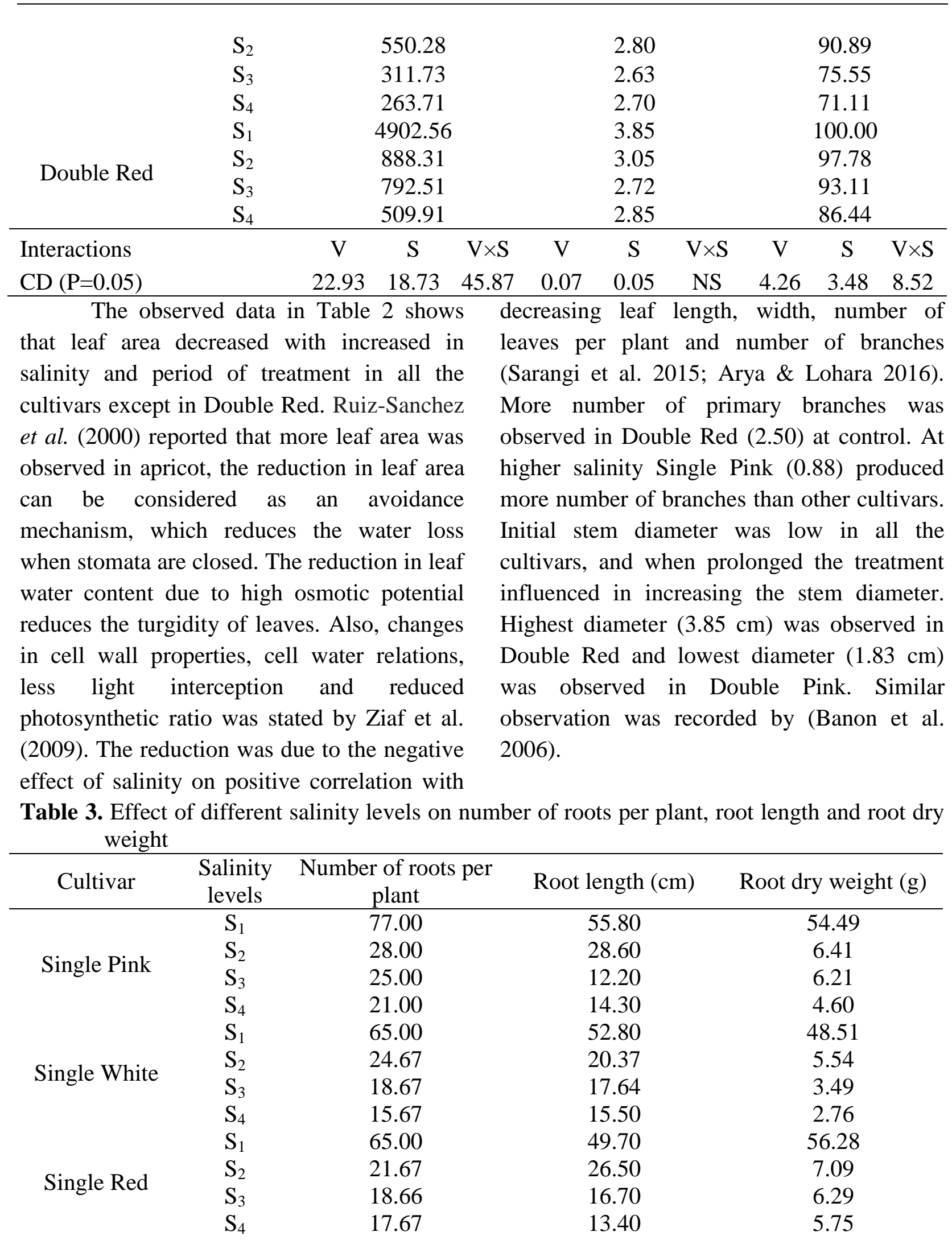




\begin{tabular}{|c|c|c|c|c|c|c|c|c|c|c|}
\hline \multirow{4}{*}{ Double Pink } & \multirow{2}{*}{$\begin{array}{l}\mathrm{S}_{1} \\
\mathrm{~S}_{2}\end{array}$} & \multicolumn{3}{|c|}{62.00} & \multicolumn{3}{|c|}{48.50} & \multicolumn{3}{|c|}{34.78} \\
\hline & & \multicolumn{3}{|c|}{21.00} & \multicolumn{3}{|c|}{19.60} & \multicolumn{3}{|c|}{3.94} \\
\hline & $\mathrm{S}_{3}$ & \multicolumn{3}{|c|}{17.00} & \multicolumn{3}{|c|}{17.50} & \multicolumn{3}{|c|}{2.60} \\
\hline & $\mathrm{S}_{4}$ & \multicolumn{3}{|c|}{13.00} & \multicolumn{3}{|c|}{13.80} & \multicolumn{3}{|c|}{2.42} \\
\hline \multirow{4}{*}{ Double White } & $\mathrm{S}_{1}$ & \multicolumn{3}{|c|}{68.00} & \multicolumn{3}{|c|}{42.50} & \multicolumn{3}{|c|}{56.33} \\
\hline & $\mathrm{S}_{2}$ & & \multicolumn{3}{|c|}{28.40} & \multicolumn{3}{|c|}{10.39} \\
\hline & $\mathrm{S}_{3}$ & \multicolumn{2}{|r|}{32.00} & & \multicolumn{3}{|c|}{18.70} & \multicolumn{3}{|c|}{8.84} \\
\hline & $\mathrm{S}_{4}$ & \multicolumn{3}{|c|}{26.00} & \multicolumn{3}{|c|}{22.30} & \multicolumn{3}{|c|}{4.43} \\
\hline \multirow{4}{*}{ Double Red } & $\mathrm{S}_{1}$ & \multicolumn{3}{|c|}{72.00} & \multicolumn{3}{|c|}{63.70} & \multicolumn{3}{|c|}{66.38} \\
\hline & $\mathrm{S}_{2}$ & \multirow{2}{*}{\multicolumn{3}{|c|}{$\begin{array}{l}54.00 \\
47.00\end{array}$}} & \multicolumn{3}{|c|}{19.50} & \multicolumn{3}{|c|}{14.85} \\
\hline & $\mathrm{S}_{3}$ & & & & \multirow{2}{*}{\multicolumn{3}{|c|}{$\begin{array}{l}17.10 \\
15.20 \\
\end{array}$}} & & 10.78 & \\
\hline & $\mathrm{S}_{4}$ & \multicolumn{3}{|c|}{38.00} & & & & \multicolumn{3}{|c|}{10.37} \\
\hline Interactions & & V & $S$ & $\mathrm{~V} \times \mathrm{S}$ & V & $S$ & $\mathrm{~V} \times \mathrm{S}$ & V & $S$ & $\mathrm{~V} \times \mathrm{S}$ \\
\hline $\mathrm{CD}(\mathrm{P}=0.05)$ & & 1.10 & 0.90 & 2.21 & 0.40 & 0.33 & 0.80 & 0.78 & 0.64 & 1.56 \\
\hline
\end{tabular}

The increased in salinity reduced the survival percentage of nerium cultivars. Double Pink shows lowest survival percentage (57.78 \%) and Double Red shows higher survivability $(86.44 \%)$ at high salinity level. In control $100 \%$ of survivability was recorded. The phenomenon of higher mortality was mainly by osmatic adjustment, which is a necessary event for plants to adopt salinity stress. Soil salinity, water shortage and high temperature limited the plant growth (Zhang et al. 1996) and reduce plant survivability percentage in arid and semiarid conditions. The reduction in root dry weight, root length and number of roots were observed and presented in Table 3. In Double Red, highest root dry weight $(10.37 \mathrm{~g})$ and maximum root numbers (38.00) was recorded at high salinity level. Lowest root dry weight $(2.42 \mathrm{~g})$ and minimum root numbers (13.00) was recorded in Double Pink. In root length, Double White cultivar was recorded highest length (22.30 $\mathrm{cm}$ ) and lowest length was recorded in Single red $(13.40 \mathrm{~cm})$ at high salinity level. This retention in root properties was depends on accumulation of sodium on root zone, which creates water deficit (Gómez-Bellot et al. 2013). The decreased water content reduces the nutrient uptake (Banon et al., 2006). In some cases, root was not penetrated beyond the ball of earth. The results were verdict to Siddiky et al. (2013). The reduction in root volume in plants exposed to salinity, may be a favourable trait for limiting their capacity to accumulate toxic ions in the shoot (Alarcon et al. 2006).

The internodal length was highest in Double White $\left(\mathrm{V}_{5}\right)$ and Single Red $\left(\mathrm{V}_{3}\right),(6.43$ and $6.37 \mathrm{~cm}$ ) respectively (Table 4). The decreasing of internodal length was high in $\mathrm{S}_{4}$ level.In cultivar Single Red, the lowest internodal length was observed $(1.95 \mathrm{~cm})$ at moderate salinity $\left(5.78 \mathrm{dS} \mathrm{m}^{-1}\right)$. The reduction in internodal length may also be, due to the toxic effect of salts (Rajendran et al. 2009), disturbing the cell division and cell enlargement in young parts of plant. This cause leaf injury and reduction in the uptake 
of major nutrients. Among the all cultivars flower initiation and Double Red takes less Single Pink takes more days (124.00 days) for days (110.33 days) for flower initiation.

Table 4. Effect of different salinity levels on internodal length and days taken to flower initiation

\begin{tabular}{|c|c|c|c|c|c|c|c|}
\hline Cultivar & Salinity levels & \multicolumn{3}{|c|}{ Internodal length $(\mathrm{cm})$} & \multicolumn{3}{|c|}{$\begin{array}{c}\text { Days taken to flower } \\
\text { initiation }\end{array}$} \\
\hline \multirow{4}{*}{ Single Pink } & $\mathrm{S}_{1}$ & \multicolumn{3}{|c|}{4.95} & \multicolumn{3}{|c|}{58.55} \\
\hline & $\mathrm{S}_{2}$ & \multicolumn{3}{|c|}{2.59} & \multicolumn{3}{|c|}{72.57} \\
\hline & $\mathrm{S}_{3}$ & \multicolumn{3}{|c|}{2.74} & \multicolumn{3}{|c|}{95.67} \\
\hline & $\mathrm{S}_{4}$ & \multicolumn{3}{|c|}{2.39} & \multicolumn{3}{|c|}{124.00} \\
\hline \multirow{4}{*}{ Single White } & $\mathrm{S}_{1}$ & \multicolumn{3}{|c|}{5.26} & \multicolumn{3}{|c|}{56.60} \\
\hline & $\mathrm{S}_{2}$ & \multicolumn{3}{|c|}{2.57} & \multicolumn{3}{|c|}{77.37} \\
\hline & $\mathrm{S}_{3}$ & \multicolumn{3}{|c|}{2.41} & \multicolumn{3}{|c|}{98.57} \\
\hline & $\mathrm{S}_{4}$ & \multicolumn{3}{|c|}{2.17} & \multicolumn{3}{|c|}{119.00} \\
\hline \multirow{4}{*}{ Single Red } & $\mathrm{S}_{1}$ & \multicolumn{3}{|c|}{6.37} & \multicolumn{3}{|c|}{59.80} \\
\hline & $\mathrm{S}_{2}$ & \multicolumn{3}{|c|}{2.57} & \multicolumn{3}{|c|}{77.63} \\
\hline & $\mathrm{S}_{3}$ & \multicolumn{3}{|c|}{1.95} & \multicolumn{3}{|c|}{94.86} \\
\hline & $\mathrm{S}_{4}$ & \multicolumn{3}{|c|}{2.18} & \multicolumn{3}{|c|}{118.50} \\
\hline \multirow{4}{*}{ Double Pink } & $\mathrm{S}_{1}$ & \multicolumn{3}{|c|}{3.15} & \multicolumn{3}{|c|}{63.75} \\
\hline & $\mathrm{S}_{2}$ & & 2.55 & & & 82.29 & \\
\hline & $\mathrm{S}_{3}$ & & 2.73 & & & 96.60 & \\
\hline & $\mathrm{S}_{4}$ & & 2.70 & & & 119.80 & \\
\hline & $\mathrm{S}_{1}$ & & 6.43 & & & 46.40 & \\
\hline Double White & $\mathrm{S}_{2}$ & & 2.52 & & & 68.33 & \\
\hline Double White & $\mathrm{S}_{3}$ & & 2.36 & & & 91.50 & \\
\hline & $\mathrm{S}_{4}$ & & 2.72 & & & 116.25 & \\
\hline & $\mathrm{S}_{1}$ & & 5.70 & & & 40.10 & \\
\hline Doubla Ped & $\mathrm{S}_{2}$ & & 3.79 & & & 59.78 & \\
\hline Double Red & $\mathrm{S}_{3}$ & & 3.48 & & & 92.00 & \\
\hline & $\mathrm{S}_{4}$ & & 3.05 & & & 110.33 & \\
\hline Interactions & & V & $\mathrm{S}$ & $\mathrm{V}$ & $\mathrm{S}$ & $\mathrm{V} \times \mathrm{S}$ & $\mathrm{V} \times \mathrm{S}$ \\
\hline $\mathrm{CD}(\mathrm{P}=0.05)$ & & 0.46 & 0.37 & 2.09 & 1.71 & 4.18 & 0.91 \\
\hline
\end{tabular}

For ornamental plant selection, not only tolerance or resistance but also with good aesthetic appearance plays a major role. In halophytes, salinity causes visual leaf injuries (like bronzing and scorching) and severe abscission of leaves. The above all parameters significantly affect the overall reduction in plant growth and morphology reported by Taibi et al. (2016) and Yan et al. (2015). Each parameter shows reduction at EC level of 7.85
$\mathrm{dS} \mathrm{m}^{-1}$. The similar findings also reported by (Munns \& Tester 2008).

\section{Conclusion}

In this study we evaluate the salt tolerant cultivars of Nerium plants on growth and morphological parameters. Each cultivar responded differently with response to salinity. Among the cultivars treated Double Red shows more tolerance capacity with high survivability and low reduction in growth 
attributes. This identification helps to choose salt tolerance plant with high ornamental and landscape utility. In future studies, standardisation of cultivar with good agronomic practices will help to renovate waste barren lands into a protective land.

\section{Acknowledgement}

I sincerely thank to professor and head, faculty staffs, members of advisory committee, AC \& RI, Madurai, my family and friends for timely support and guidance to complete my study.

\section{Reference}

Allakhverdiev SI, Sakamoto A, Nishiyama Y, Inaba M \& Murata N. 2000. Ionic and osmotic effects of $\mathrm{NaCl}$-induced inactivation of photosystems I and II in Synechococcus sp. Plant Physiology, 123 (3): 1047-1056.

Álvarez S, Gómez-Bellot MJ, Castillo M, Bañón S \& Sánchez-Blanco MJ. 2012. Osmotic and saline effect on growth, water relations, and ion uptake and translocation in Phlomispurpurea plants. Environmental and Experimental Botany, 78: 138-145.

Arya R \& Lohara RR. 2016. Enhancing forest productivity through afforestation on arid salt affected sandy soils in Rajasthan. Journal of Agriculture and Ecology, 1: 59-70.

Bañón S, Ochoa J, Franco JA, Alarcón JJ \& Sánchez-Blanco MJ. 2006. Hardening of oleander seedlings by deficit irrigation and low air humidity. Environmental and Experimental Botany, 56(1): 36-43.
Choukr-Allah R. 1996. The potential of halophytes in the development and rehabilitation of arid and semi-arid zones. Halophytes and Biosaline Agriculture, 13.

Flowers TJ \& Yeo AR. 1995. Breeding for salinity resistance in crop plants: where next. Functional Plant Biology, 22(6): 875-884.

Gómez-Bellot MJ, Alvarez S, Castillo M, Bañón S, Ortuño MF \& Sánchez-Blanco MJ. 2013. Water relations, nutrient content and developmental responses of Euonymus plants irrigated with water of different degrees of salinity and quality. Journal of Plant Research, 126(4): 567-576.

Munns R \& Termaat A. 1986. Whole-plant responses to salinity. Functional Plant Biology, 13(1): 143-160.

Munns R \& Tester M. 2008. Mechanisms of salinity tolerance. Annual Review of Plant Biology, 59: 651-681.

Pedrero F, Kalavrouziotis I, Alarcón JJ, Koukoulakis P \& Asano T. 2010. Use of treated municipal wastewater in irrigated agriculture-Review of some practices in Spain and Greece. Agricultural Water Management, 97(9): 1233-1241.

Rai S, Luthra R \& Kumar S. 2003. Salttolerant mutants in glycophytic salinity response (GSR) genes in Catharanthus roseus. Theoretical and Applied Genetics, 106 (2): 221-230.

Rajendran K, Tester M \& Roy SJ. 2009. Quantifying the three main components 
of salinity tolerance in cereals. Plant, Cell \& Environment, 32 (3): 237-249.

Rodrıguez P, Torrecillas A, Morales MA, Ortuno MF \& Sánchez-Blanco MJ. 2005. Effects of $\mathrm{NaCl}$ salinity and water stress on growth and leaf water relations of Asteriscus maritimus plants. Environmental and Experimental Botany, 53(2): 113-123.

Roy SJ, Negrão S \& Tester M. 2014. Salt resistant crop plants. Current Opinion in Biotechnology, 26: 115-124.

Ruiz-Sánchez MC, Domingo R, Torrecillas A \& Pérez-Pastor A. 2000. Water stress preconditioning to improve drought resistance in young apricot plants. Plant Science, 156(2): 245-251.

Sarangi SK, Maji B, Singh S, Burman D, Mandal S, Sharma DK \& Haefele SM. 2015. Improved nursery management further enhances the productivity of stress-tolerant rice cultivars in coastal rainfed lowlands. Field Crops Research, 174: 61-70.

Siddiky MA, Sardar PK, Hossain MM, Khan MS \& Uddin MK. 2012. Screening of different tomato varieties in saline areas of Bangladesh. International Journal of Agriculture Research, Innnovation and Technology, 2(1): 13-18.
Taïbi K, Taïbi F, Abderrahim LA, Ennajah A, Belkhodja M \& Mulet JM. 2016. Effect of salt stress on growth, chlorophyll content, lipid peroxidation and antioxidant defence systems in Phaseolus vulgaris L. South African Journal of Botany, 105: 306-312.

Whitcomb CE. 1988. Plant production in containers. Lacebark Publications.

Yan N, Marschner P, Cao W, Zuo C \& Qin W. 2015. Influence of salinity and water content on soil microorganisms. International Soil and Water Conservation Research,3(4): 316-323.

Zhang J, Klueva N \& Nguyen HT. 1996. Plant adaptation and crop improvement for arid and semiarid environments. In Proceedings of the Fifth International Conference on Desert Development (Vol. 2, pp. 12-17).

Ziaf K, Amjad M, Pervez MA, Iqbal Q, Rajwana IA \& Ayyub MUHAMMAD. 2009. Evaluation of different growth and physiological traits as indices of salt tolerance in hot pepper (Capsicum annuum L.). Pakistan Journal of Botany, 41(4): 1797-1809. 